\title{
Drug interaction resources: mind the gaps
}

\section{Louise Grannell \\ Senior medicines information pharmacist, \\ Alfred Health, Melbourne}

\section{Keywords}

drug information,

enzalutamide,

drug interactions,

pharmacokinetics

Aust Prescr 2020;43:18-23 https://doi.org/10.18773/ austprescr.2020.005

\section{SUMMARY}

Drug interactions can lead to significant toxicity or loss of clinical effect. The risks increase with the number of drugs the patient takes.

General and specialised drug interaction resources are available. Access to up-to-date electronic resources is encouraged.

There are gaps in the information on interactions for new drugs, those with complicated metabolism and drugs with limited use. It may be necessary to use multiple resources to find the information.

When assessing information about interactions, clinicians should evaluate the relevance for each patient. In high-risk situations, expert advice can be valuable.

Clinicians should report new or unusual drug interactions to the Therapeutic Goods Administration.

\section{Introduction}

Treatment regimens are becoming increasingly complex, with a greater risk of drug interactions. Drug-drug interactions can cause significant patient harm. This is either due to drug toxicity or loss of efficacy. For example, voriconazole' and clarithromycin increase simvastatin concentrations risking rhabdomyolysis, while rifampicin decreases the anticoagulant effect of warfarin. Sometimes interacting drugs are intentionally co-prescribed, for example diltiazem can be used to increase ciclosporin concentrations. Drug-drug interactions can also occur with complementary medicines.

Clinicians should use the available drug-drug interaction resources, but be aware that, although advice may be similar from each resource, discrepancies also occur. It is important that potential drug-drug interactions are evaluated for their clinical significance and relevance to each patient. To identify interactions it is first necessary to have an accurate list of the patient's prescription, complementary and over-the-counter medicines. Drugs given by other routes, such as topical and inhaled, should also be considered.

\section{Mechanisms}

The mechanisms of drug-drug interactions vary. ${ }^{2,3}$ Clinicians need to understand the drug's pharmacology including metabolic pathways to determine both pharmacodynamic (altered effect) and pharmacokinetic (altered concentration) interactions. It can be particularly complex to assess the clinical significance of interactions from multiple drugs which each have a potentially additive effect on a shared action, such as QT prolongation, ${ }^{4}$ increasing serotonin, or lowering of the seizure threshold. Patient factors, such as organ dysfunction, age, concurrent medical conditions, electrolyte disturbances and genetic factors, may influence the risk or severity of the interaction.

Toxicity from drug-drug interactions can occur not only when starting or changing doses, but also when ceasing treatment, for example the strong induction effect of carbamazepine on cytochrome enzymes takes at least two weeks to reverse. Some drugs take a long time to be completely cleared such as amiodarone. ${ }^{5}$ Patients should be monitored accordingly. ${ }^{6}$

\section{Drug interaction resources}

General and specialised resources are available to help assess the clinical impact of drug interactions. These include dedicated drug-drug interaction resources for antiretroviral drugs, hepatitis $\mathrm{C}$ therapies, antifungals, anticancer drugs and complementary medicines (Table 1). A subscription may be needed.

The Australian Medicines Handbook (AMH) provides practical information on drug interactions considered likely to be clinically important. When appropriate it gives specific information on drug metabolism, but does not include primary references.

MIMS and the Australian Drug Information (AusDI) interaction checkers, Stockley's Drug Interactions and Lexicomp assign their own 'severity/risk rating' or 'importance' for interactions. They give the probable mechanism of interaction, advise on actions to be taken and include clinical evidence and supporting, or in some cases disputing, references. 
Some of the information used to develop drug-drug interaction resources includes:

- Australian and international product information

- primary literature (case reports and clinical papers)

- guidance from international regulatory bodies, such as the Therapeutic Goods Administration (TGA) and the UK Medicines and Healthcare products Regulatory Agency (MHRA).

\section{Gaps}

Depending on the information used and their editorial criteria, resources may give different advice about interactions especially when assigning clinical significance. In some cases, interaction advice may be lacking entirely. These gaps can occur due to variations in product information, or when the metabolism of a drug is not well defined. A particularly challenging area for advice about drug-drug interactions is with new drugs, such as enzalutamide (Table 2), and older re-purposed drugs, such as pristinamycin. Clinical experience of these drugs in combination with other drugs is limited. Sometimes interaction information is extrapolated from other drugs in the same class or those with similar metabolism. Interactions may not be included in the resources until they have been reported to the TGA or published as case reports.

The available resources usually provide information about interactions between two drugs, however patients may be taking multiple drugs with many potential interactions. There is no resource currently available that can provide information about the overall risk of interactions with different combinations of drugs. Medicines information pharmacists may be able to provide advice in these cases.

\section{Drug interactions - search strategy}

When looking for information, clinicians are strongly encouraged to have access to the online interaction checking tool in the AMH. Similar tools in MIMS or AusDI are also valuable. For newer drugs, those with complex metabolism or for unusual drug-drug combinations, there may be a need to refer to multiple resources.

In order to predict the potential for a drug-drug interaction, cytochrome tables, such as in the AMH or Flockhart, are useful, along with the mechanism of action given in the product information. For specific drug classes, free access to specialised resources is available (Table 1). Electronic resources should be used to improve the currency of information. However, clinicans are reminded that not even electronic resources can be considered completely up to date, due to the speed of publication of medical literature.

Hospital and medicines information pharmacists have access to specialised resources, such as Stockley's or Lexicomp, along with locally researched drug-drug interaction resources. However, access to medicines information services and clinical pharmacologists varies by state. Pharmacists working in general practice are also a valuable resource, but are not widely available. ${ }^{7}$

\section{Electronic decision support}

Drug interaction alerts are included as decision support at the point of care in electronic prescribing and dispensing systems. For example, some interaction alerts in general practice software are referenced to the MIMS interaction checker.

There are concerns that systems generate so many warnings that there is a risk of alert fatigue. This has led to calls in the USA, particularly in the hospital environment, to standardise the information in electronic systems, with the development of methods to filter out unimportant drug-drug interaction alerts. ${ }^{8}$ However, an international or local consensus on standardisation has not yet been reached..$^{8,9}$

\section{Real-world data}

For new drugs there may be few clinical trials or case reports of drug-drug interactions in 'realworld' conditions involving patients with multiple comorbidities taking many drugs. For example, many resources about antiretroviral drug-drug interactions are based on theoretical information, so the clinical relevance in everyday practice is unknown. A Spanish group has therefore established a website that allows clinicians to submit cases of antiretroviral drug-drug interactions. $^{10}$

Clinicians are encouraged to publish case reports of new or unusual drug-drug interactions, as these are valuable in informing clinical practice. Reporting suspected drug and vaccine interactions to the Therapeutic Goods Administration is also encouraged via the TGA Adverse Event Management System.

\section{Conclusion}

Clinicians should consult drug-drug interaction information, evaluate it and consider its relevance for their patient. For new drugs or when information is inconsistent or absent, it may be necessary to refer to multiple interaction resources or seek expert advice, for example from a medicines information pharmacist. $<$

Conflict of interest: none declared 


\section{REFERENCES}

1. Doran E, ledema J, Ryan L, Coombes I. Drug interactions: fatal rhabdomyolysis following voriconazole and simvastatin. Aust Prescr 2012;35:88-9. https://doi.org/10.18773/ austprescr.2012.040

2. Snyder BD, Polasek TM, Doogue MP. Drug interactions: principles and practice. Aust Prescr 2012;35:85-8. https://doi.org/10.18773/austprescr.2012.037

3. Day RO, Snowden L, McLachlan AJ. Life-threatening drug interactions: what the physician needs to know. Intern Med J 2017;47:501-12. https://doi.org/10.1111/imj.13404

4. Isbister GK. Risk assessment of drug-induced QT prolongation. Aust Prescr 2015;38:20-4. https://doi.org/ 10.18773/austprescr.2015.003

5. Srinivasan M, Ahmad L, Bhindi R, Allahwala U. Amiodarone in the aged. Aust Prescr 2019:42:158-62. https://doi.org/ 10.18773/austprescr.2019.051

6. Tong EY, Kowalski M, Yip GS, Dooley MJ. Impact of drug interactions when medications are stopped: the often forgotten risks. Med J Aust 2014;200:345-6. https://doi.org/ 10.5694/mja13.11361
7. Mackie KF, Duncan AJ, Fineberg D, Vujovic O. Specialist pharmacist in general practice coordinating HIV patient care to manage a complicated drug-drug interaction: case report. J Pharm Pract Res 2019;49:291-5. https://doi.org/10.1002/jppr.1563

8. Tilson H, Hines LE, McEvoy G, Weinstein DM, Hansten PD, Matuszewski K, et al. Recommendations for selecting drug-drug interactions for clinical decision support. Am J Health Syst Pharm 2016;73:576-85. https://doi.org/ 0.2146/ajhp150565

9. Page NJ, Bysari MT, Westbrook JI. Selection and use of the decision support alerts in electronic medication management systems in Australian hospitals: a survey of implementers. J Pharm Pract Res 2019;49:142-9. https://doi.org/10.1002/jppr.1479

10. Clinical cases DDIs [Internet]. http://www.clinicalcasesddis.com/ ddis [cited 2019 Dec 24]

\section{Table 1 Online drug interaction resources}

\begin{tabular}{|c|c|c|c|c|c|}
\hline Area & $\begin{array}{l}\text { Resource and web } \\
\text { link }\end{array}$ & $\begin{array}{l}\text { Interaction } \\
\text { checker* }\end{array}$ & Comment & Origin & Availability \\
\hline \multirow[t]{6}{*}{ General } & \multirow[t]{2}{*}{$\begin{array}{l}\text { Individual product } \\
\text { information }\end{array}$} & \multirow[t]{2}{*}{ No } & \multirow[t]{2}{*}{$\begin{array}{l}\text { Not exhaustive and not routinely updated } \\
\text { with new clinically important drug-drug } \\
\text { interactions }\end{array}$} & \multirow[t]{2}{*}{ Australia } & $\begin{array}{l}\text { Free via TGA website - } \\
\text { lists most current } \\
\text { product information }\end{array}$ \\
\hline & & & & & $\begin{array}{l}\text { Also on MIMs/AusDI } \\
\text { (check currency) }\end{array}$ \\
\hline & \multirow[t]{4}{*}{$\begin{array}{l}\text { Australian Medicines } \\
\text { Handbook }\end{array}$} & $\begin{array}{l}\text { Yes - capacity to } \\
\text { search interactions } \\
\text { between: }\end{array}$ & $\begin{array}{l}\text { Provides practical information on clinically } \\
\text { important interactions }\end{array}$ & \multirow[t]{4}{*}{ Australia } & \multirow[t]{4}{*}{ Subscription required } \\
\hline & & $\begin{array}{l}\text { between: } \\
\text { - } 2 \text { individual } \\
\text { drugs }\end{array}$ & $\begin{array}{l}\text { Information on drug metabolism including } \\
\text { quick reference tables for drugs and CYP } \\
\text { enzymes and P-glycoprotein }\end{array}$ & & \\
\hline & & - 2 drug classes & No primary references provided & & \\
\hline & & $\begin{array}{l}\text { - } 1 \text { individual } \\
\text { drug and entire } \\
\text { drug class }\end{array}$ & & & \\
\hline
\end{tabular}

MIMS Drug Interaction

Database

AusDI Drug Interaction

Database

Stockley's Drug $\quad$ Yes

Specialised

Interactions

Lexicomp Drug Yes

Interactions

\section{Yes}

Yes

Yes

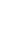

Backbone for some GP prescribing software

The content of these interactions

Australia

Subscription required databases can differ from each other

Authorative resource preferred by most UK medicines information pharmacists

Although a useful resource, it tends to extrapolate interaction advice from other drugs in the same class or other drugs with the same metabolism. It is sometimes overcautious and includes drug-drug interactions, even when evidence or even plausibility is lacking

Flockhart Table No Novides tables of cytochrome substrates,
inhibitors and inducers

YouScript $\quad$ Yes

USA - Indiana

Free University School of Medicine

\section{USA}

Subscription required

USA Subscription

\section{Subscription required}

Also available with full UpToDate subscription Most hospitals have access
Considers individual patient genetic phenotypes and drug interaction risk, quick guide to pharmacokinetic data for drug exposure changes 


\section{Table 1 Online drug interaction resources (continued)}

\begin{tabular}{|c|c|c|c|c|c|}
\hline Area & $\begin{array}{l}\text { Resource and web } \\
\text { link }\end{array}$ & $\begin{array}{l}\text { Interaction } \\
\text { checker* }\end{array}$ & Comment & Origin & Availability \\
\hline \multirow[t]{6}{*}{$\begin{array}{l}\text { Specific drug } \\
\text { classes }\end{array}$} & $\begin{array}{l}\text { Antiretroviral } \\
\text { HIV Drug Interactions }\end{array}$ & Yes & $\begin{array}{l}\text { Easy to use - can print a personalised } \\
\text { drug-drug interaction report }\end{array}$ & $\begin{array}{l}\text { UK - University } \\
\text { of Liverpool }\end{array}$ & Free \\
\hline & $\begin{array}{l}\text { Antiretroviral } \\
\text { HIV Clinical } \\
\text { Cases Drug-Drug } \\
\text { Interactions - 'real- } \\
\text { world cases' }\end{array}$ & Yes & $\begin{array}{l}\text { Search outcomes from real-world clinical } \\
\text { cases }\end{array}$ & $\begin{array}{l}\text { Spain - FLS } \\
\text { Science, plus } \\
\text { international } \\
\text { collaboration }\end{array}$ & $\begin{array}{l}\text { Free - but need to } \\
\text { register } \\
\text { Available since May } \\
2019\end{array}$ \\
\hline & $\begin{array}{l}\text { Antiretroviral and } \\
\text { hepatitis C direct- } \\
\text { acting antivirals } \\
\text { HIV/HCV Drug } \\
\text { Therapy Guide }\end{array}$ & Yes & $\begin{array}{l}\text { Easy to use - can print a personalised } \\
\text { drug-drug interaction report }\end{array}$ & $\begin{array}{l}\text { Canada - } \\
\text { Toronto General } \\
\text { Hospital }\end{array}$ & Free \\
\hline & $\begin{array}{l}\text { Hepatitis } \mathrm{C} \text { direct- } \\
\text { acting antivirals } \\
\text { HEP Drug Interactions }\end{array}$ & Yes & $\begin{array}{l}\text { Easy to use - can print a personalised } \\
\text { drug-drug interaction report }\end{array}$ & $\begin{array}{l}\text { UK - University } \\
\text { of Liverpool }\end{array}$ & Free \\
\hline & $\begin{array}{l}\text { Antifungal } \\
\text { Fungal Pharmacology }\end{array}$ & Yes & $\begin{array}{l}\text { Easy to use - can print a personalised } \\
\text { drug-drug interaction report }\end{array}$ & $\begin{array}{l}\text { Netherlands } \\
\text { - Radboud } \\
\text { University } \\
\text { Medical Centre }\end{array}$ & Free \\
\hline & $\begin{array}{l}\text { Oncology } \\
\text { Cancer Drug } \\
\text { Interactions database }\end{array}$ & Yes & $\begin{array}{l}\text { Easy to use - can print a personalised } \\
\text { drug-drug interaction report }\end{array}$ & $\begin{array}{l}\text { UK and } \\
\text { Netherlands } \\
\text { - University } \\
\text { of Liverpool } \\
\text { and Radboud } \\
\text { University }\end{array}$ & Free \\
\hline $\begin{array}{l}\text { Complementary } \\
\text { medicines }\end{array}$ & Natural Medicines & Yes & $\begin{array}{l}\text { Includes published drug-drug interaction } \\
\text { case reports and theoretical interactions } \\
\text { based on CYP metabolism } \\
\text { Can print patient handouts, multiple } \\
\text { languages }\end{array}$ & USA & Subscription required \\
\hline
\end{tabular}

Various other resources include interactions with complementary medicines: AusDI, Stockley's Herbal Medicines Interactions

* Interaction checkers generate interactions between all possible pairs of drugs but cannot provide information about the overall combination of multiple drugs

TGA Therapeutic Goods Administration

AusDI Australian Drug Information

CYP cytochrome P450 


\section{Table 2 Comparison of online drug interaction resources for enzalutamide*}

\begin{tabular}{|c|c|c|c|}
\hline Resource & $\begin{array}{l}\text { Oxycodone } \\
\text { (metabolised by CYP3A4 } \\
\text { (major), CYP2D6 (minor)) }\end{array}$ & $\begin{array}{l}\text { Mirtazapine } \\
\text { (metabolised by } \\
\text { CYP3A4) }\end{array}$ & $\begin{array}{l}\text { Rivaroxaban } \\
\text { (metabolised by CYP3A4, } \\
\text { substrate of P-glycoprotein) }\end{array}$ \\
\hline $\begin{array}{l}\text { Enzalutamide } \\
\text { product information } \\
\text { (Revised } 2019 \text { Sep 4) }\end{array}$ & $\begin{array}{l}\text { No direct recommendation. } \\
\text { In interaction section - } \\
\text { 'analgesics' listed but not } \\
\text { specifically oxycodone }\end{array}$ & $\begin{array}{l}\text { No direct } \\
\text { recommendation }\end{array}$ & $\begin{array}{l}\text { No direct recommendation. } \\
\text { In interaction section - } \\
\text { anticoagulants, only warfarin } \\
\text { listed }\end{array}$ \\
\hline $\begin{array}{l}\text { Australian } \\
\text { Medicines } \\
\text { Handbook (AMH) }\end{array}$ & $\begin{array}{l}\text { Although no interaction } \\
\text { found, need to consider } \\
\text { pharmacokinetic and } \\
\text { background information } \\
\text { provided, which suggests } \\
\downarrow \text { oxycodone. Consider an } \\
\text { alternative or monitor pain relief } \\
\text { and adjust oxycodone dose }\end{array}$ & $\begin{array}{l}\text { Although no interaction } \\
\text { found, need to consider } \\
\text { pharmacokinetic and } \\
\text { background information } \\
\text { provided, which } \\
\text { suggests } \downarrow \text { mirtazapine. } \\
\text { Possible additive } \\
\text { seizure risk }\end{array}$ & $\begin{array}{l}\text { Although no interaction } \\
\text { found, need to consider } \\
\text { pharmacokinetic and } \\
\text { background information } \\
\text { provided and extrapolate } \\
\text { from other potent CYP3A4 } \\
\text { inducers. } \downarrow \text { rivaroxaban }\end{array}$ \\
\hline $\begin{array}{l}\text { MIMS Interaction } \\
\text { Database }\end{array}$ & No interaction listed & No interaction listed & No interaction listed \\
\hline $\begin{array}{l}\text { Stockley's Drug } \\
\text { Interactions }\end{array}$ & $\begin{array}{l}\text { Theoretical evidence predicts } \\
\downarrow \text { oxycodone }\end{array}$ & $\begin{array}{l}\text { Theoretical evidence } \\
\text { predicts } \downarrow \text { mirtazapine }\end{array}$ & $\begin{array}{l}\text { Theoretical evidence predicts } \\
\downarrow \text { rivaroxaban, but confusing } \\
\text { as no information to suggest } \\
\text { enzalutamide’s effect on } \\
\text { P-glycoprotein\# }\end{array}$ \\
\hline $\begin{array}{l}\text { Lexicomp Drug } \\
\text { Interactions }\end{array}$ & $\begin{array}{l}\text { Risk Rating D: need to } \\
\text { consider dose modification as } \\
\downarrow \text { oxycodone }\end{array}$ & $\begin{array}{l}\text { Risk Rating D: need } \\
\text { to consider dose } \\
\text { modification as } \\
\downarrow \text { mirtazapine }\end{array}$ & $\begin{array}{l}\text { Risk Rating X: avoid - see } \\
\text { comments }\end{array}$ \\
\hline $\begin{array}{l}\text { Micromedex Drug } \\
\text { Interactions }\end{array}$ & Major interaction. $\downarrow$ oxycodone & No interaction listed & No interaction listed \\
\hline $\begin{array}{l}\text { Cancer Drug } \\
\text { Interactions }\end{array}$ & $\begin{array}{l}\text { Do not co-administer\# } \\
\text { If co-administration clinically } \\
\text { necessary, close monitoring } \\
\text { required }\end{array}$ & $\begin{array}{l}\text { Do not co-administer\# } \\
\text { If co-administration } \\
\text { clinically necessary, } \\
\text { may need to increase } \\
\text { mirtazapine dose } \\
\text { as enzalutamide } \\
\downarrow \text { mirtazapine }\end{array}$ & $\begin{array}{l}\text { Do not co-administer\# } \\
\text { If co-administration clinically } \\
\text { necessary, close monitoring } \\
\text { of anti-Xa recommended }\end{array}$ \\
\hline
\end{tabular}

* Resources in this table reviewed online 2019 Aug 23.

Notes

Enzalutamide, an anti-androgen for metastatic castration-resistant prostate cancer, will be increasingly seen in the community. It is an unrecognised, yet major contributor to drug interactions and has a particularly complex metabolism. It is a potent CYP3A4 inducer, moderate CYP2C9 and CYP2C19 inducer, but its effect on P-glycoprotein is conflicting in the manufacturer's information. This, combined with the limited published reports of clinical outcomes from drug interactions to date, has resulted in variation or, in some cases, an absence of reporting of drug-drug interactions. In addition, the extended half-life (approximate mean 6 days) makes drug-drug interactions difficult to predict, with maximum induction potential occurring up to one month from starting enzalutamide, and effects on enzymes continuing for at least one month after cessation. Management of anticoagulation in patients taking enzalutamide is particularly challenging and input from a haematologist is recommended.

Enzalutamide has complex metabolism:

- substrate CYP2C8 (major), CYP3A4 (minor)

- induces CYP3A4 (potent), CYP2C9 and CYP2C19 (moderate)

- product information says in vitro enzalutamide inhibits P-glycoprotein but it also says it may act as an inducer

- induces CYP2B6, OAT, UGT

\# Resource comments that these combinations have not actually been clinically studied

CYP cytochrome P450

$\downarrow$ reduces drug concentration

An A3 single-page version of this table is available online. 
Apixaban

(metabolised by CYP3A4, substrate of P-glycoprotein)

No direct recommendation. In interaction section - anticoagulants, only warfarin listed

\section{Dabigatran}

(substrate of P-glycoprotein)

Use with caution as dabigatran is a

P-glycoprotein substrate and a drug

with narrow therapeutic window
Although no interaction found, need to consider pharmacokinetic and background information provided. However AMH does not suggest enzalutamide has any effect on P-glycoprotein, so would assume no interaction

No interaction listed

No interaction listed

Use with caution as may increase dabigatran

Theoretical evidence predicts $\downarrow$ apixaban, but confusing as no information to suggest enzalutamide's effect on P-glycoprotein\#

Risk Rating X: avoid

No interactions identified

No interaction listed

No interaction listed

Do not co-administer\#

Potential Interaction\#

If co-administration clinically necessary, close monitoring for anti-Xa recommended
Although no interaction found, need to consider pharmacokinetic and covided. P-glycoprotein, so would assume no interaction
Difficult to quickly determine drugdrug interactions if you do not know how the other drug is metabolised

\section{Comments}

Enzalutamide is not listed in specific P-glycoprotein substrate/ inhibitor/inducer table which makes interaction interpretation difficult
Personal communication with MIMS editorial team (August 2019) that this content is under review

Enzalutamide not listed in specific P-glycoprotein substrate/inhibitor/ inducer table, although role of $\mathrm{P}$-glycoprotein is mentioned in dabigatran/enzalutamide interaction

For rivaroxaban, there is a statement that in Canada these combinations would say 'use with caution' rather than 'avoid'

Micromedex, a US database, less commonly referred to for drug-drug interaction advice 